\title{
「メディカルフォトニクスによる脳研究の現状と将来」 の特集によせて
}

\author{
江田 英雄 \\ 光産業創成大学院大学
}

脳研究を加速させるきっかけの一つは，1990 年のブッシュ大統領 (当時) 演説であった. 脳の 10 年と名付けら れたその内容は，現在アメリカの政府サイトから検索して知ることができる．日本では「脳の世紀」プロジェク トがスタートし, 医学のみならず, 分子生物学, 心理学, 認知科学, 工学などを含む学際的な取り組みが注目さ れた．現在に至るまで，技術の発展も手助けして，さまざまな研究が進められ成果が上がっている.

ところが脳研究は手強い．第一に研究対象と自らの研究の立ち位置を明確に意識する必要がある. ヒトを対象 とした脳研究の目的の一つが, 脳機能マッピングすなわち脳機能局在の解明であるが, 必要な装置, 必要なスペッ クが研究対象によって異なるのである.一般に脳活動は, 神経細胞の発火, 代謝物質の変動, 酸素供給のための ヘモグロビンの変動に大別できる，これらは大脳生理学の範疇であり，さまざまな装置を用いて計測が試みられ るのだが，何を計測して何を議論したいのかを明確にせね攼ならない，第二に“こころ”の問題がある. 哲学者 デカルトやベルグソンなどの精力的な仕事にも関わらず，こころの働きと脳活動とが一致するかどうか，学問的 には, 決着がついていない. 第三に研究手法の問題がある. 脳研究の手法はアクティベーションスタディに基づ くことが多い．脳に何らかの刺激を与えて，その刺激に対する反応を計測する．反応はノイズやゆらぎを含むも のであるから統計的に判断せねばならない。この統計解析手法が非常に洗練された形で脳研究に応用されている ため，それを熟知する必要がある。

このような多梯性を極める脳研究に対して，光技術を用いてどのように立ち向かうか．光技術で何ができて， それは他の計測手法とどのように異なるかをまとめるべく，本特集を企画した，光の波長情報を積極的に使っ て分光学の手法により, 生体のへモグロビン変化を推測することができる. 近赤外分光法 (NIRS, Near Infrared Spectroscopy)，および，そのイメージング技術に基づくへモグロビン変化の情報が, 脳研究にも有効なものとなっ ている．今回は，教育学への応用に関する投稿をお願いした.

一方，他の計測手法としては，神経細胞の電気磁気的信号を計測する脳波 (EEG)，脳磁図 (MEG), 代謝物質 計測も可能とするポジトロン放射トモグラフィ(PET)，へモグロビン変化の信号に基づく情報を計測する機能的 磁気共鳴イメージング (fMRI) などがある.このうちで, PET は体内に注入した放射性同位元素の分裂によって 発生するガンマ線を, 最終的に光検出器で計測する. 信号の由来の明確さから, 他の計測手法と比べて信頼性が 高い，放射性同位元素を使うために，頻繁に計測するのは困難であるが，統計手法も使われるために，光技術の 研究者としても重要な知識と考える.今回は，非可聴音の影響というチャレンジングな内容で投稿をお願いした。

当初の企画から異なる形で読者の皆様に打届けすることになってしまった点は, 企画者の対応不足に起因する ものであり, 深くお詫び申し上げる.レーザー医学における脳研究への取り組みについては続けて研究を紹介す ベく，今後の課題とさせていただければ幸いである. 